\title{
Effect of Fertility Levels and Foliar nutrition sprays on Growth and Yield Parameters of Field Pea (Pisum sativum L.)
}

\author{
Rajesh Meena*, R. K. Yadav, M. K. Sharma, S. L. Yadav, V. K. Yadav, \\ R. K. Meena and A. K. Meena \\ Agricultural Research Station, (Agriculture University), Ummedganj, Kota-324001, India \\ *Corresponding author
}

\section{A B S T R A C T}

\begin{tabular}{|l|}
\hline Key w o r d s \\
$\begin{array}{l}\text { Foliar nutrition, } \\
\text { Fertility level, } \\
\text { productivity and } \\
\text { Yield }\end{array}$ \\
\hline Article Info \\
\hline $\begin{array}{l}\text { Accepted: } \\
\text { 20 June } 2020 \\
\text { Available Online: } \\
\text { 10 July } 2020\end{array}$ \\
\hline
\end{tabular}

\section{Introduction}

Field pea (Pisum sativam L.) is one of the most important pulse crops among the various grain legumes grown in India. According to Vavilov (1951), it is native to Mediterranean region of Southern Europe \& Western Asia; belong to the family Leguminaceae (Sub. family Papilionaceae) is cool season nutritive crop. It is a short-duration pulse crop is grown in many parts of country. It provides nutritious food rich in protein. A $100 \mathrm{~g}$ of
A field experiment was conducted at Agricultural Research Station (Agriculture University), Kota (Rajasthan) During Rabi seasons (2019-20). The experiment comprised of 3 fertility levels (i.e.75\%, 100\% and 125\%) were kept in main plots and 5 levels of foliar nutrition (i.e. water spray, $2 \%$ Neem coated urea, NPK 19:19:19, NPK 17:44:0 \& NPK 0:0:50@ 0.5 \% PF\& PI in sub plots. Fertility level was drilled 4-5 cm deep into the soil before Field pea sowing in earmarked strips and subsequently foliar nutrition were sprayed at critical stages i.e. flower initiation and pod development. Result revealed that fertility level $25 \mathrm{~kg} \mathrm{ha}^{-1} \mathrm{~N}, 50 \mathrm{~kg} \mathrm{ha}^{-1} \mathrm{P}, 25 \mathrm{~kg} \mathrm{ha}^{-1} \mathrm{~K}_{2} \mathrm{O} \mathrm{kg} \mathrm{ha} \mathrm{kg}^{-1}, 25 \mathrm{~kg} \mathrm{ha}^{-1} \mathrm{~S}$ and $25 \mathrm{~kg} \mathrm{ha}^{-}$ ${ }^{1} \mathrm{ZnSo}_{4} \mathrm{~kg} \mathrm{ha}^{-1}$ before sowing recorded significantly higher pods plant-1 (62.2), grain yield (2310 $\mathrm{kg} \mathrm{ha}^{-1}$ ) and straw yield (3555 kg ha-1) respectively, while, maximum biological yield (5865 kg ha ${ }^{-1}$ ) was fetched with fertility $125 \%$ RDF. Foliar application of NPK (19:19:19) @ $0.5 \%$ at flower initiation \& pod development stages recorded significantly higher pods plant-1 (63.2), grain yield (2261 kg ha-1), straw yield (3436 kg ha-1) and biological yield (5697 $\mathrm{kg} \mathrm{ha}^{-1}$ ) being on par with NPK 19:19:19 respectively. 
pea producing state in India like Karnataka, Madhya Pradesh, Rajasthan, West Bengal, Punjab, Assam, Haryana, Uttar Pradesh, Uttarakhand, Himachal Pradesh, Bihar and Orissa. It produced 143.6 lakh tones from 76.3 lakh ha with an average productivity of $1884 \mathrm{~kg} \mathrm{ha}^{-1}$ (Ministry of Agriculture and Farmer Welfare, Annual report, 2017-18).

This imbalanced and inadequate fertilizers use and coupled with low efficiency of chemical fertilizers declined tremendously under intensive cultivation in recent years. Variation in nutrients supply is a natural phenomenon and some of them may be sufficient where others deficient. The nutrient supply adverse effects on the seed yield of field pea, soil health, depletion of soil organic carbon, lower moisture retention, decrease in water stable aggregates and available $\mathrm{Zn}$ status have been identified as reasons of low productivity

Nutrient management practices is the main component for sustainable field pea production along with foliar application of water soluble fertilizers at appropriate stages of growth may also ameliorate the nutrient deficiency as well as mitigate the heat stress. It is therefore to measure the adoption of improved appropriate water conserving technologies for enhancing the productivity and profitability of field pea. The effective dose of foliar nutrition at critical stages for enhancing productivity and profitability of field pea under Vertisols (Ram, et al., 2018).

\section{Materials and Methods}

A field experiment was conducted at Agricultural Research Station of the Agriculture University, Kota (Rajasthan), during Rabi seasons 2019-20. The experiment comprised of 3 fertility levels (i.e. $75 \%, 100 \%$ and $125 \%$ RDF were kept in main plots and 5 levels of foliar nutrition (i.e. water spray, $2 \%$ urea, NPK 19;19:19, NPK 17:44:0 \& NPK
0:0:50@ 0.5 \%PF \& PI in sub plots. The experiment was laid out in Factorial Randomised Block Design and replicated three times. The soil of the experimental field was clay loam, slightly alkaline in reaction ( $\mathrm{pH} 7.8)$, medium in available $\mathrm{N}(173.5 \mathrm{~kg}$ ha $\left.{ }^{1}\right)$ \& K (280.5 kg ha $\left.{ }^{-1}\right)$ and low in available $\mathrm{P}$ (10.24 kg ha $\mathrm{kg}^{-1}$ \& sulphur (11.0 $\left.\mathrm{kg} \mathrm{ha}^{-1}\right)$. Fertility was drilled in soil before field pea sowing in earmarked strips and subsequently foliar nutrition were sprayed at critical stages i.e. flower initiation and pod development. The recommended dose of fertilizer $(25 \mathrm{~kg} \mathrm{~N}$, $50 \mathrm{~kg} \mathrm{P}, 25 \mathrm{~kg} \mathrm{~K} 2 \mathrm{O}, 25 \mathrm{~kg} \mathrm{~S}$ and $25 \mathrm{~kg} \mathrm{Zn}$ ) was drilled in the soil at the time of sowing. The field pea variety "IPFD 10-12" was used for experimental purpose and sown on 17th November, 2019. In each plot five plants were randomly selected and tagged to record biometric observations on growth and yield attributes. At maturity data on plant height, branches plant ${ }^{-1}$, pods plant ${ }^{-1}$, seeds pod $^{-1}$, 1000- seed weight, biological yield and grain yield were recorded. Harvest index was calculated by dividing economical yield by total biomass production. Net returns as well as $\mathrm{B}$ : $\mathrm{C}$ ratios were also worked out. All data were subjected to analysis of variance.

\section{Results and Discussion}

\section{Growth and yield attributes}

Application of fertility levels on growth parameters such as the plant stand $\mathrm{m}^{-2}$ and test weight was found non-significant. The maximum number of plant height at harvest, number of branches, pods plant ${ }^{-1}$, seeds plant ${ }^{-}$ 1 , were observed with application of $125 \%$ RDF which was significantly superior to other fertility levels. As a result, almost all growth attributes of crop resulted into significant improvement due to fertilizers. These results also confirms with the findings of Choudhary and Yadav, (2011) observed the significant response to sulphur levels was observed in all 
growth parameters i.e. plant height, number of branches, pods plant ${ }^{-1}$, seeds plant ${ }^{-1}$.

The observation on plant population was recorded at harvest and data are presented in (Table1). Plant population ranged between 30 to 30.9 plant $\mathrm{m}^{-2}$ at harvest the respectively. The results revealed that there was nonsignificant at harvest. The maximum number of plant height (150.80) at harvest, number of branches (3.27), pods $\operatorname{plant}^{-1}(63.2)$, seeds plant $^{-1}(3.81)$ seed, straw and biological yield were observed with application of NPK 19:19:19 at $0.5 \%$ PF \& PI which was significantly superior to other foliar nutrition spray. Foliar application of nutrients at flower initiation and pod development stages had positive effect on increasing growth parameters. Ram et al., (2018) revealed that foliar application of NPK (19:19:19) at $0.5 \%$ at flower initiation \& pod development stages recorded significantly tallest plant, higher number of branches plant ${ }^{-1}$.

Mudalagiriyappa et al., (2016) recorded that increased yield attributes such as number of pods plant ${ }^{-1}$, pod weight plant $^{-1}$, and grain yield.

Table.1 Effect of fertility levels and foliar nutrient spray on growth Attribute of Field Pea

\begin{tabular}{|c|c|c|c|c|c|}
\hline Treatment & $\begin{array}{l}\text { Plant height }(\mathrm{cm}) \\
\text { at harvest }\end{array}$ & $\begin{array}{l}\text { No. of } \\
\text { branches per } \\
\text { plant }\end{array}$ & $\begin{array}{l}\text { Pods per } \\
\text { plant }\end{array}$ & $\begin{array}{l}\text { Seed per } \\
\text { pods }\end{array}$ & $\begin{array}{l}\text { Test weight } \\
\text { (g) }\end{array}$ \\
\hline \multicolumn{6}{|l|}{ Fertility levels } \\
\hline $75 \%$ RDF & 137.1 & 2.9 & 53.2 & 3.3 & 148.6 \\
\hline $100 \%$ RDF & 148.3 & 3.0 & 59.9 & 3.5 & 148.0 \\
\hline $125 \%$ RDF & 150.2 & 3.2 & 62.2 & 3.9 & 150.2 \\
\hline $\operatorname{SEm} \pm$ & 2.69 & 0.1 & 1.8 & 0.1 & 1.3 \\
\hline CD (5\%) & 7.80 & 0.2 & 5.2 & 0.3 & NS \\
\hline \multicolumn{6}{|l|}{ Foliar nutrients spray } \\
\hline $\begin{array}{l}\text { F1. Water spray } \\
\text { (control) }\end{array}$ & 134 & 2.8 & 51.7 & 3.3 & 149.2 \\
\hline $\begin{array}{r}\text { F2. NCU 2\% } \\
\text { \& PI }\end{array}$ & 147.0 & 3.0 & 58.2 & 3.6 & 148.8 \\
\hline $\begin{array}{l}\text { F3. NPK (19: 19: } \\
\text { 19) } 0.5 \% \text { at PF \& PI }\end{array}$ & 150.8 & 3.3 & 63.2 & 3.8 & 148.7 \\
\hline $\begin{array}{l}\text { F4. NPK (17: 44: 0) } \\
\text { 0.5\% at PF \& PI }\end{array}$ & 148.5 & 3.2 & 62.3 & 3.6 & 149.0 \\
\hline $\begin{array}{l}\text { F5. NPK ( 0: 0: 50) } \\
\text { 0.5\% at PF \& PI }\end{array}$ & 145.7 & 2.9 & 56.7 & 3.5 & 149.1 \\
\hline $\operatorname{SEm} \pm$ & 3.48 & 0.1 & 2.3 & 0.1 & 1.6 \\
\hline CD (5\%) & 10.07 & 0.3 & 6.7 & NS & NS \\
\hline
\end{tabular}


Table.2 Effect of Fertility level and foliar nutrition on yield of Field pea

\begin{tabular}{|c|c|c|c|c|}
\hline Treatment & $\begin{array}{c}\text { Seed yield } \\
\left(\mathrm{kg} \mathrm{ha}^{-1}\right)\end{array}$ & $\begin{array}{l}\text { Straw yield } \\
\left(\mathrm{kg} \mathrm{ha}^{-1}\right.\end{array}$ & $\begin{array}{l}\text { Biological yield } \\
\left(\mathrm{kg} \mathrm{ha}^{-1}\right)\end{array}$ & $\begin{array}{c}\text { Harvest index } \\
(\%)\end{array}$ \\
\hline \multicolumn{5}{|l|}{ Fertility levels } \\
\hline 75\% RDF & 1798 & 2847 & 4646 & 38.7 \\
\hline $100 \%$ RDF & 2212 & 3213 & 5424 & 40.8 \\
\hline $125 \%$ RDF & 2310 & 3555 & 5865 & 39.5 \\
\hline SEm \pm & 45.3 & 76.8 & 81.5 & 0.8 \\
\hline CD (5\%) & 131.3 & 222.6 & 236.1 & NS \\
\hline \multicolumn{5}{|l|}{ Foliar nutrients spray } \\
\hline $\begin{array}{l}\text { F1. Water spray } \\
\text { (control) }\end{array}$ & 1955 & 3058 & 5014 & 38.8 \\
\hline $\begin{array}{l}\text { F2. NCU } 2 \% \text { at PF \& } \\
\text { PI }\end{array}$ & 2078 & 3181 & 5259 & 39.5 \\
\hline $\begin{array}{l}\text { F3. NPK (19: 19: 19) } \\
0.5 \% \text { at PF \& PI }\end{array}$ & 2261 & 3436 & 5697 & 39.8 \\
\hline $\begin{array}{l}\text { F4. NPK (17: 44: 0) } \\
0.5 \% \text { at PF \& PI }\end{array}$ & 2151 & 3203 & 5354 & 40.2 \\
\hline $\begin{array}{l}\text { F5. NPK ( 0: 0: 50) } \\
0.5 \% \text { at PF \& PI }\end{array}$ & 2089 & 3146 & 5235 & 40.0 \\
\hline SEm \pm & 58.5 & 99.2 & 105.2 & 1.1 \\
\hline $\operatorname{CD}(\overline{5} \%)$ & 169.5 & NS & 304.9 & NS \\
\hline
\end{tabular}

In conclusion the study suggests that fertility level $125 \%$ RDF before field pea sowing and subsequently foliar spray of either NPK (19:19:19)@ 0.5\% or NPK 17:44:0 at flower initiation and pod development was found effective for increasing grain yield and economics of field pea. Hence, Fertility along with foliar application of either NPK 19:19:19 or NPK 17:44:0 may become a practically convenient and economically feasible and viable option in water-stressed areas for increasing agricultural productivity with environmental sustainability.

\section{References}

Anonymous (2016-17), Annual report. DES, Ministry of Agriculture \& Farmers' Welfare, Government of India, Krishi Bhawan .

Bhat, T.A., Gupta, M., Ganai, M.A., Ahanger,
R.A. and Bhat, H.A. (2013). Yield, soil health and nutrient utilization of field pea (Pisum sativum L.) as affected by phosphorus and Biofertilizers under subtropical conditions of Jammu. International Journal of Modern Plant and Animal Science 1(1):1-8.

Choudhary, G. L. and Yadav, L. R., 2011, Effect of fertility levels and foliar nutrition on cowpea productivity. J. Food Leg., 24(1): 67-68.

Mudalagiriyappa, M., Ali, S., Ramachandrappa, B.K., Basavaraja, P.K. and Kiran. (2016). Effect of foliar application of water soluble fertilizer on nutrient uptake and reproductive efficiency of Chickpea (Cicer arietinum L.).The Bioscan, An International Quaternaly Journal of Environmental Life Sciences 11(3): 1601-1604.

Ram, B., Punia, S.S., Tetarwal, J.P., Meena, 
D.S., Singh, P. and Choudhary, H.R. (2018). Effect of Hydrogel and foliar nutrition sprays on productivity and profitability of lentil under rainfed situation of south eastern plain zone of
Rajasthan. International Journal of Advanced Scientific Research and management, ISSN-2455-6378.

\section{How to cite this article:}

Rajesh Meena, R. K. Yadav, M. K. Sharma, S. L. Yadav, V. K. Yadav, R. K. Meena and Meena, A. K. 2020. Effect of Fertility Levels and Foliar nutrition sprays on Growth and Yield Parameters of Field Pea (Pisum sativum L.). Int.J.Curr.Microbiol.App.Sci. 9(07): 2415-2419. doi: https://doi.org/10.20546/ijcmas.2020.907.283 